\title{
Impact of Lead Toxicity on Germination, Plant Growth, Yield and Metal Uptake in Radish Plants
}

\author{
Elkhatib, H.A. ${ }^{1}$
}

\begin{abstract}
The effects of lead on radish plants (Raphanus sativus L.) were investigated to understand the impact of lead accumulation on seed germination, plant growth and yield. Two germination and pot experiments were carried out during the 2006 and 2007 seasons,at the Faculty of Agriculture, Damanhour Branch, Alexandria University. Seeds and plants were treated with different concentrations of $\mathrm{Pb}: 0,100,200$ and $300 \mathrm{ppm}$. Pb contents in both root and shoot tissues gradually increased with increasing the applied $\mathrm{Pb}$ concentration. More lead was accumulated in root tissues than in shoot tissues. The higher concentration of lead $(300 \mathrm{ppm})$ caused a significant decrease in seed germination, plant height, leaves fresh and dry weights, leaves area and yield of (Raphanus sativus L.) Two polynomial quadratic equations were established to express the response of radish yield to $\mathrm{Pb}$ contamination. The experimental yield values and the corresponding calculated values were not significantly different as tested by high values of correlation coefficient.

\section{INTRODUCTION}

Lead $(\mathrm{Pb})$ is one of the major heavy metals of the antiquity and has gained considerable importance as a potent environmental pollutant (Talanova et al. 1999). The background concentration of $\mathrm{Pb}$ in uncontaminated soil lies within the range of 10-50 ppm. However, in the soil with low-level contamination, $\mathrm{Pb}$ concentration can be expected to range from 30 to $100 \mathrm{mg} / \mathrm{kg}$ (Davies 1995).With rapid development in industry all around the world since the 20th century, the inputs of $\mathrm{Pb}$ to agricultural soils have been occurring through the combustion of gasoline containing $\mathrm{Pb}$ additives, human activities such as mining, smelting, electroplating, energy and fuel production, power transmission, intensive agriculture, sludge dumping and military operations (Nedelkoska and Doran, 2000). Excess Lead in environment can cause serious problems to all organisms (Herrero et al. 2003). Prenatal and early postnatal exposure to $\mathrm{Pb}$ resulted in damage to the central nervous systems. The damage is characterized by diminished intelligence, shortened attention span, and slowed reaction time. These effects are irreversible, untreatable, and lifelong (Wasserman et al.1997). The absorption and transport of $\mathrm{Pb}$ by crops are of great concern, especially its accumulation in the edible part. $\mathrm{Pb}$ belongs among nonessential metals for plants and has no known biological function (Wierzbicka 1995). The levels of $\mathrm{Pb}$ in soils that are toxic to plant are not easy to evaluate. However, it is generally agreed that soil $\mathrm{Pb}$ concentration ranging from 100 to $500 \mathrm{ppm}$ are considered to be excessive (Kabata-Pendias, and Pendias, 1992). $\mathrm{Pb}$ inhibitory effects may be due to interference with enzymes essential for normal metabolic and development (Van Assche and Clijsters 1990), photosynthetic processes (Fodor et al. 1996), water and mineral nutrients absorption (Burzynski 1987), and changes in cell ultrastructure (Stefanov et al.1995). The $\mathrm{Pb}$ content of plant grown on $\mathrm{Pb}$-polluted areas is generally, highly correlated with the $\mathrm{Pb}$ concentration in soil, although the relationship differs among organs of the plants (Rooney et al. 1999). The uptake, transport, and accumulation of $\mathrm{Pb}$ by plants are strongly governed by soil and plant factors, and they differ significantly with plant species (Yang et al.1993). The inhibitory and toxic effects of lead on seed germination and seedling growth have been reported in Brassica pekinensis (Xiong 1998), and Pisum sativum (Wierzbicka and Obidzinska 1998). $\mathrm{Pb}$ absorbed and accumulated in different plant tissues with the highest amount in the root tissues (Kumar et al., 1995).Pb accumulation in roots takes place by binding with polysaccharides (Seregin and Ivanove, 1998) or binding to the cell walls in the roots and xylem vessels (Fathi, 1983) and thus might become immobile. Results of Jaja and Odoemena (2004) on tomato showed that increasing lead levels, significantly, decreased root length, shoot length, leaf area, fresh and dry weight. The response of Brassica junicea to lead was also studied by Begonia et al. (1998) who reported that root dry matter, total leaf area and shoot dry weight were reduced by lead treatment.

The leaves and roots of radish (Raphanus sativus L.) are edible; extracts of the leaves, flowers. and pods are useful against diseases caused by plant pathogenic bacteria, Also radish can be grown in a wide range of climates and their roots have useful medicinal property in the treatment of urinary complaints, piles, and gastro-diarrhea. (Chattopadhyay et al. 2006).

Although seed germination represents an initial and crucial phase in the life cycle of plants, virtually little information is available on the impact of lead on

${ }^{1}$ Horticulture Dept. Faculty of Agriculture,

Damanhour Branch, Alex. Univ.

Received June1, 2009, Accepted June30, 2009 
the action of gradually increasing concentrations of $\mathrm{Pb}$ on germinating radish seeds, plant growth and yield. Therefore this study was undertaken with a view to find out the effects of lead stress on seed germination, growth, biochemical constituents and mineral status of radish.

\section{MATERIAL AND METHODS}

\section{Seed germination experiments}

Two germination experiments were carried out in Petri dishes during April of 2006 and 2007to determine the effect of lead on seeds germination, length of primary roots. Seeds of radish (Raphanus sativus L.) Balady cultivars were surface sterilized with $0.1 \%$ mercuric chloride solution and rinsed several times with distilled water. Sterilized glass petri dishes of approximately $15 \mathrm{~cm}$ in diameter, each containing 2 Whatman No. 1 filter papers were used as sowing container and media. Ten seeds of radish were spread uniformly in each of the Petri dishes. Pb Pollution was established by adding $20 \mathrm{ml}$ of lead acetate solution at the various concentrations of $0,100,200,300 \mathrm{ppm}$ into the Petri dishes before sowing. Distilled water was used as the control treatment. Germination study was observed for 5 days. Percentage $(\%)$ germination was recorded when the radicle reached one $\mathrm{mm}$ in length. Each treatment was replicated five times and the solutions were replenished every other day. The germination percentage of the seeds, root length and lateral roots number were finally determined for each treatment. Root length was measured by placing the root on 1-mm squared graph paper. Tolerance indices (T.I.) were determined through use of the following formula given by Iqbal and Siddiqui (1992):

Mean root length in metal solution

T.I. $=$ $\times$

100

Mean root length in distilled water

\section{Pot experiments}

Two pot experiments were conducted on April during the two successive growing seasons of 2006 and 2007 at the Faculty of agriculture Damanhour Branch, Alexandria University. Plants were grown in pots in untreated soil (control) and in soil to which various concentrations of $\mathrm{Pb}$ had been added (100, 200, and 300 $\mathrm{mg} \mathrm{kg}^{-1}$ soil). Each pot contained $4 \mathrm{~kg}$ of air-dried soil (Clay loam, $\mathrm{ECe}=1.4$ and $1.7 \mathrm{mmhos} / \mathrm{cm} ; \mathrm{pH} 7.5$ and7.8; $\mathrm{Pb} 1.12$ and $1.26 \mathrm{ppm}$ in the seasons of 2006 and 2007 respectively) to determine the effect of lead on the vegetative growth characters, lead content, yield of radish plants (cv. Balady) .

The physical and chemical characteristics of the Soil were determined according to the methods reported by Page et al. (1982). Available lead was determined according to the method mentioned by Cottenie et al. (1982). and measured by atomic absorption spectrophotometer (AAS).

\section{Experimental Layout}

The experiments were sat in completely randomized design with three replicates. Leads as lead acetate at the concentration of $0.0,100,200$ and 300 ppm was used after dissolving in tap water and thoroughly mixed with the soil. In each pot 8 seeds were sown. All pots were irrigated with tap water whenever it was needed to keep the moisture in soil at about $70 \%$ of the total water holding capacity of the soil during the experimental period. Plants were thinned to three plants per pot one week after germination. Plants were harvested 50 days after sowing at edible stage. Roots and shoots were dried at 60C and weighed for the measurement of various growth parameters, chemical and mineral constituents.

\section{Morphological Parameters}

Morphological parameters, including shoot and root length, fresh and dry weight of leaves, and leaves area per plant. Leaves area were measured and calculated using the weight method as described by Fayed (1997).

\section{Chemical Analysis}

The collected plant samples were washed with tap water to remove the adhered soil particles and then washed several time with distilled water. The plant samples were oven dried at $70 \mathrm{C}^{?}$ for 48 hours and ground in a mill with stainless steel blades .

Wet digestion procedure was performed according to Chapman and Pratt (1978). Lead contents were analyzed by atomic absorption spectrophotometer according to Cottenie et al., (1982). Phosphorus percentage was determined calorimetrically as reported by Jackson, (1967). Potassium percentage was determined by flame photometer as described by Brown and Lilliand (1946).

All obtained data were statistically analyzed using SAS software program (1996). Comparisons among the means of different treatments were achieved using the revised least significant difference procedure at $P=0.05$ level as illustrated by Al-Rawy and Khalf-Allah (1980).

\section{RESULTS AND DISCUSSION}

\section{Effect of lead on seed germination}

The effects of various concentrations of lead on seed germination of Raphanus sativus cultivar Balady are shown in Table(1). The results demonstrated that the percentage germination of radish seeds was not 
significantly affected by lead treatments at lower concentration $(100 \mathrm{ppm} \mathrm{Pb})$ compared to the control treatment in both seasons. However, the effects appeared significant at 200 and $300 \mathrm{ppm} \mathrm{Pb}$ treatments compared to control in both seasons. Lead treatment at $300 \mathrm{ppm}$ reduced the germination percentage by 34.01 and $33.29 \%$; 32.54 and 34.42 compared to the control after 3 and 5 days in the first and second seasons, respectively. Similar results have also been observed in Brassica Pekinensis by Xiong (1998). Hameed et al. (2001) also found that lead caused great reduction in germination percentage of Spinancea oleracea and Lycopersicum esculentum. The inhibitory effect of heavy metals on seed germination could be due to ionic toxicity or due to an osmotic effect (Redmann, 1974) or to the decreased level of auxin resulting from enhanced destruction of auxin by metal ion (Mukherji and DasGupta, 1972).

\section{Effect of lead on root growth}

Lead treatments, significantly decreased the root length (Table 2) at all concentrations than the control at 72 and 120 hours, in both seasons. After 72 hours, the reductions were $15.37,33.03$ and $47.71 \%$; and 9.78, 34.13 and $49.27 \%$ of the control in the first and second seasons at lead concentration of 100, 200 and 300 ppm, respectively. Meanwhile, after120 hours, the reductions were $21.79 \%, 36.19 \%$ and $51.95 \%$; and $14.91 \%$, $38.55 \%$ and $50.76 \%$ of the control in the first and second seasons at lead concentration of 100, 200 and
$300 \mathrm{ppm}$, respectively. These findings are in line with those reported by Liu et al., (1994) on onion. They found that $\mathrm{Pb}$ treatments inhibited the root growth of Allium cepa at concentration of $10^{-4} \mathrm{M}$. Obroucheva et al. (1998) reported that lead treatments affected both cell growth processes, i.e. cell division and cell elongation.

The lead inhibitory effect on cell division was noticed through the reduction of meristem size and decreased number of mature cells formed in a day. The inhibition of root growth after exposure to $\mathrm{Pb}$ may be due to a decrease in $\mathrm{Ca}$ in the root tips, leading to a decrease in cell division or cell elongation (Haussling et al., 1988).

Early seedling growth was also inhibited in tomato and eggplant (Khan and Khan, 1983).Radish seedlings showed also low percentage of tolerance to lead treatment as compared to control. Tolerance to lead treatment at $300 \mathrm{ppm}$ exhibited the lowest level as compared to lower concentrations in both seasons (Table 3). Iqbal and Siddiqui (1992) found also gradual decreases in plants growth with the increase in concentration of $\mathrm{Pb}$. Tolerance to lead in some plant species was very low at higher concentrations. They concluded that the reason of low tolerance to lead might be due to occurrence of changes in physiological functions that took place during germination of those seedlings.

Table 1. Effect of lead acetate on seed germination of radish, during the seasons of 2006 and 2007

\begin{tabular}{cccccc}
\hline Pb & \multicolumn{2}{c}{ Season 2006 } & \multicolumn{3}{c}{ Season 2007 } \\
\cline { 2 - 6 }$(\mathbf{p p m})$ & $\begin{array}{c}\text { Germination } \\
\text { percentage after 72 } \\
\text { hours }\end{array}$ & $\begin{array}{c}\text { Germination } \\
\text { percentage after 120 } \\
\text { hours }\end{array}$ & $\begin{array}{c}\text { Germination } \\
\text { percentage after 72 } \\
\text { hours }\end{array}$ & $\begin{array}{c}\text { Germination } \\
\text { percentage after 120 } \\
\text { hours }\end{array}$ \\
\hline 0 & $82.26 \mathrm{~A}^{*}$ & $98.24 \mathrm{~A}$ & $83.36 \mathrm{~A}$ & $97.47 \mathrm{~A}$ \\
100 & $76.74 \mathrm{~A}$ & $92.75 \mathrm{AB}$ & 78.54 & $\mathrm{~A}$ & $93.33 \mathrm{AB}$ \\
200 & $66.45 \mathrm{C}$ & $84.36 \mathrm{~B}$ & 64.39 & $\mathrm{~B}$ & $86.76 \mathrm{~B}$ \\
300 & $54.28 \mathrm{D}$ & $65.54 \mathrm{C}$ & $56.23 \mathrm{C}$ & $63.92 \mathrm{C}$ \\
\hline
\end{tabular}

*Values having a common alphabetical letter (s), do not significantly differ, using the revised L.S.D. test at $\mathrm{P}=0.05$.

Table 2. Root growth responses of radish seedling to various lead levels during the seasons of 2006 and 2007

\begin{tabular}{cccccc}
\hline Pb $(\mathbf{p p m})$ & \multicolumn{2}{c}{ Length of roots $(\mathbf{c m})$ after $\mathbf{7 2}$ hours } & \multicolumn{2}{c}{ Length of roots $(\mathbf{c m})$ after 120 hours } \\
& $\mathbf{2 0 0 6}$ & $\mathbf{2 0 0 7}$ & $\mathbf{2 0 0 6}$ & $\mathbf{2 0 0 7}$ \\
\hline 0 & $4.36 \mathrm{~A}^{*}$ & $5.42 \mathrm{~A}$ & $5.14 \mathrm{~A}$ & $6.64 \mathrm{~A}$ \\
100 & $3.69 \mathrm{~B}$ & $4.89 \mathrm{~A}$ & $4.02 \mathrm{~B}$ & $5.65 \mathrm{~B}$ \\
200 & $2.92 \mathrm{C}$ & $3.57 \mathrm{~B}$ & $3.28 \mathrm{BC}$ & $4.08 \mathrm{C}$ \\
300 & $2.28 \mathrm{D}$ & $2.75 \mathrm{C}$ & $2.47 \mathrm{C}$ & $3.27 \mathrm{D}$ \\
\hline
\end{tabular}

*Values having a common alphabetical letter (s), do not significantly differ, using the revised L.S.D. test at $\mathrm{P}=0.05$. 
Table 3. Root tolerance indices of radish seedling to various lead levels, during the seasons of 2006 and 2007

\begin{tabular}{ccccc}
\hline \multirow{2}{*}{$\mathbf{P b} \quad$} & Roots tolerance indices (cm) after 72 & \multicolumn{2}{c}{ Roots tolerance indices (cm) after 120 } \\
& \multicolumn{2}{c}{ hours } & \multicolumn{2}{c}{ hours } \\
& $\mathbf{2 0 0 6}$ & $\mathbf{2 0 0 7}$ & $\mathbf{2 0 0 6}$ & $\mathbf{2 0 0 7}$ \\
\hline 100 & $84.63 \mathrm{~A}^{*}$ & $90.22 \mathrm{~A}$ & $78.21 \mathrm{~A}$ & $85.09 \mathrm{~A}$ \\
200 & $66.97 \mathrm{~B}$ & $65.87 \mathrm{~B}$ & $63.81 \mathrm{~B}$ & $61.45 \mathrm{~B}$ \\
300 & $52.29 \mathrm{C}$ & $50.73 \mathrm{C}$ & $48.05 \mathrm{C}$ & $49.24 \mathrm{C}$ \\
\hline
\end{tabular}

*Values having a common alphabetical letter (s), do not significantly differ, using the revised L.S.D. test at $\mathrm{P}=0.05$.

\section{Effect of lead on vegetative growth characters:}

The decrease in growth of radish was gradual and more depressed with increase in $\mathrm{Pb}$ concentration from 100 to $300 \mathrm{ppm}$.Root and shoots length of radish plants under lead treatment at 50 days are presented in Table (4). The root and shoot length decreased as the concentration of $\mathrm{Pb}$ in the soil increased. The lowest shoot and root length values were observed at $300 \mathrm{ppm}$ $\mathrm{Pb}$. The reductions were 44.09 and $51.9 ; 35.15 \%$ and $37.83 \%$, compared to control treatment for shoot and root length in the first and second seasons respectively. Both leaves fresh and dry weights were significantly affected by $\mathrm{Pb}$ soil levels (Table 4). The effects of lead levels were severe at higher $\mathrm{Pb}$ concentrations. Reductions of leaves fresh and dry weight at $300 \mathrm{ppm}$ relative to control plants were 61.76, 69.97\%; and $57.74,65.18 \%$ in the first and second seasons respectively. The reduction in roots development under excess $\mathrm{Pb}$ conditions was reported earlier for several other plants (Tomar et al., 2000). Pb at high levels may inhibit root and shoot growth directly by inhibiting cell division or cell elongation, or by a combination of both, resulting in limited exploration of the soil volume for uptake and translocation of nutrients and water (Khan and Frakland, 1983).

Leaf area of radish plants decreased with increased $\mathrm{Pb}$ content of the soil (Table 4). The reductions of leaf area of radish plants at the highest levels $(300 \mathrm{ppm} \mathrm{Pb}$ ) were 38.44 and $48.15 \%$ compared to control in first and second seasons respectively. Similar reductions in total leaf area due to excess lead have been observed by khan and Frakland, (1983). The decrease in leaf area at high concentrations of $\mathrm{Pb}$ could be attributed to either a reduction in the number of cells or to a reduction in cell size as reported by Tomar et al. 2002 on mung bean.

Data presented in Table (4) illustrated that lead at all levels significantly inhibited root fresh and dry weights of radish plants and the inhibition was more severe at the highest $\mathrm{Pb}$ level. The reduction of root fresh and dry weight of radish plants grown in soil polluted with $300 \mathrm{ppm} \mathrm{Pb}$ reached about 58.9 and $58.4 \%$ (1st season) and 65.58 and $60.06 \%$ (2nd season) compared to the untreated plants, respectively, The negative effects of lead on root fresh and dry weights of radish plants may be due to its inhibitory effects on the uptake and translocation of some major and micro elements within plant roots un(Kabata Pendias and Pendias 1992); on the activity of some enzymes as well as on biosynthesis of photosynthetic pigments which were reflected on radish yield.

\section{Biochemical Constituents}

Photosynthetic pigments, such as chlorophyll a, chlorophyll $\mathrm{b}$, and total chlorophyll contents of radish leaves decreased significantly with increasing $\mathrm{Pb}$ levels in the soil (Table 5). Excessive $\mathrm{Pb}$ treatment at the concentration of $300 \mathrm{ppm}$ decreased significantly chlorophyll a, chlorophyll $\mathrm{b}$ and the total chlorophyll by $38.24 \%, 52.5 \%$ and $43.52 \%$ in first season and by $45.45,50.52$ and $47.31 \%$, in the second season respectively. Excessive $\mathrm{Pb}$ might interfere with the synthesis of chlorophyll because of $\mathrm{Pb}$ treatments presumably block the synthesis and activity of enzyme proteins responsible for chlorophyll biosynthesis (Ahmed and Tajmir- Riahi 1993) or by causing impaired uptakes of essential elements such as $\mathrm{Mg}$ and Fe by plants (Burzynski, 1987).

\section{Phosphorous and potassium contents}

At all levels of applied $\mathrm{Pb}$ the concentrations of $\mathrm{P}$ and $\mathrm{K}$ in leaves and roots of radish plants decreased significantly compared to corresponding control values. As well as, the accumulation of phosphorus and potassium were also found to be high in tops than in roots (Table 6). Radish leaves showed reductions of 35.71 and 32.61 in P content at $300 \mathrm{ppm} \mathrm{Pb}$ compared to 25.31 and 30.88 in K content in 2006 and 2007 seasons, respectively. On the other hand at the same lead treatment, reductions of 35.94 and 36.83; and 33.22 and 36.17 were detected in roots content of $\mathrm{P}$ and $\mathrm{K}$ in the first and second seasons respectively. Similar trends were also reported by Walker et al. (1997), who found that $\mathrm{Pb}$ decreased the uptake of $\mathrm{K}, \mathrm{Ca}, \mathrm{Mg}, \mathrm{Fe}$ and $\mathrm{NO}_{3}{ }^{-}$ in seedlings of Cucumis sativus and decreased the uptake of $\mathrm{Ca}, \mathrm{Mg}, \mathrm{K}$ and $\mathrm{P}$ in Zea mays . Also, Paivoke (2002) reported that $\mathrm{Pb}$ influenced the overall distribution of nutritional elements within the different organs of the plant. Phosphorus content was found to be negatively correlated with soil $\mathrm{Pb}$. 
Table 4. The effect of lead on morphological parameters of radish plants during 2006 and 2007seasons

\begin{tabular}{|c|c|c|c|c|c|c|c|}
\hline $\begin{array}{c}\text { Lead } \\
\text { concentration } \\
\text { ppm }\end{array}$ & $\begin{array}{l}\text { Leaves } \\
(\mathrm{cm}) \\
\end{array}$ & $\begin{array}{c}\text { Roots } \\
\text { length } \\
(\mathrm{cm})\end{array}$ & $\begin{array}{c}\text { Leaves fresh } \\
\text { weight } \\
\text { (g) }\end{array}$ & $\begin{array}{l}\text { Leaves dry } \\
\text { weight } \\
\text { (g) }\end{array}$ & $\begin{array}{l}\text { Leaves } \\
\text { area } \\
\left(\mathrm{cm}^{2}\right)\end{array}$ & $\begin{array}{l}\text { Root fresh } \\
\text { weight } \\
\text { (g) }\end{array}$ & $\begin{array}{c}\text { Root dry } \\
\text { weight } \\
\text { (g) }\end{array}$ \\
\hline \multicolumn{8}{|c|}{2006} \\
\hline 0 & $29.12 \mathrm{~A}$ & $14.28 \mathrm{~A}$ & $49.69 \mathrm{~A}$ & $4.52 \mathrm{~A}$ & $902.13 \mathrm{~A}$ & $40.41 \mathrm{~A}$ & $2.69 \mathrm{~A}$ \\
\hline 100 & $24.13 \mathrm{~A} \mathrm{~B}$ & $13.18 \mathrm{~A}$ & $38.26 \mathrm{~B}$ & 3.75 A B & $822.08 \mathrm{~A}$ & $33.10 \mathrm{AB}$ & $2.25 \mathrm{AB}$ \\
\hline 200 & $20.59 \mathrm{BC}$ & $11.29 \mathrm{~B}$ & $27.29 \mathrm{C}$ & 2.72 B C & $660.24 \mathrm{~B}$ & $25.73 \mathrm{C}$ & $1.62 \mathrm{~B} \mathrm{C}$ \\
\hline 300 & $16.28 \mathrm{C}$ & $09.26 \mathrm{C}$ & $19.00 \mathrm{D}$ & $1.91 \mathrm{C}$ & $555.38 \mathrm{C}$ & 16.61 D & $1.12 \mathrm{C}$ \\
\hline \multicolumn{8}{|c|}{2007} \\
\hline 0 & $30.27 \mathrm{~A}$ & $15.73 \mathrm{~A}$ & $57.31 \mathrm{~A}$ & $4.94 \mathrm{~A}$ & $1011.5 \mathrm{~A}$ & $44.63 \mathrm{~A}$ & $3.13 \mathrm{~A}$ \\
\hline 100 & $27.64 \mathrm{~B}$ & $13.09 \mathrm{~B}$ & $42.54 \mathrm{~B}$ & $4.13 \mathrm{~B}$ & 966.24 B & $35.24 \mathrm{~B}$ & $2.54 \mathrm{~B}$ \\
\hline 200 & $19.27 \mathrm{C}$ & $12.25 \mathrm{~B}$ & $26.24 \mathrm{C}$ & $2.57 \mathrm{C}$ & $634.81 \mathrm{C}$ & $24.47 \mathrm{C}$ & $1.50 \mathrm{C}$ \\
\hline 300 & $14.56 \mathrm{D}$ & 9.78 & $17.21 \mathrm{D}$ & $1.72 \mathrm{D}$ & $524.45 \mathrm{D}$ & $15.36 \mathrm{D}$ & $1.25 \mathrm{D}$ \\
\hline
\end{tabular}

Table 5. Effect of $\mathrm{Pb}$ on chlorophyll concentration of leaves of radish plants during 2006 and 2007 seasons

\begin{tabular}{|c|c|c|c|}
\hline $\begin{array}{l}\text { Lead concentration } \\
\text { ppm }\end{array}$ & $\begin{array}{c}\text { chlorophyll a } \\
\text { (mg/g dry wt) in } \\
\text { leaves }\end{array}$ & $\begin{array}{c}\text { chlorophyll b } \\
\text { (mg/g dry wt) in leaves }\end{array}$ & Total chlorophyll \\
\hline \multicolumn{4}{|c|}{2006} \\
\hline 0 & $3.4 \mathrm{~A}$ & $2.0 \mathrm{~A}$ & $5.4 \mathrm{~A}$ \\
\hline 100 & $3.0 \mathrm{~B}$ & $1.7 \mathrm{~A}$ & $4.7 \mathrm{~B}$ \\
\hline 200 & $2.7 \mathrm{~B}$ & $1.2 \mathrm{~B}$ & $3.9 \mathrm{C}$ \\
\hline 300 & $2.1 \mathrm{C}$ & $0.95 \mathrm{~B}$ & 3.05D \\
\hline \multicolumn{4}{|c|}{2007} \\
\hline 0 & $3.3 \mathrm{~A}$ & $1.9 \mathrm{~A}$ & $5.2 \mathrm{~A}$ \\
\hline 100 & $3.2 \mathrm{~A}$ & $1.6 \mathrm{AB}$ & $4.8 \mathrm{~A}$ \\
\hline 200 & $2.4 \mathrm{~B}$ & $1.3 \mathrm{BC}$ & $3.7 \mathrm{C}$ \\
\hline 300 & $1.8 \mathrm{C}$ & $0.94 \mathrm{C}$ & $2.74 \mathrm{D}$ \\
\hline
\end{tabular}

*Values having a common alphabetical letter (s), do not significantly differ, using the revised L.S.D. test at $\mathrm{P}=0.05$

Table 6. Effect of $\mathrm{Pb}$ on elemental content of leaves of radish plants during 2006 and 2007 seasons

\begin{tabular}{|c|c|c|c|c|}
\hline Lead concentration & ppm & $\mathbf{P \%}$ & $\mathbf{K} \%$ & $\mathbf{P b}(\mathrm{ppm})$ \\
\hline \multicolumn{5}{|c|}{2006} \\
\hline 0 & & $0.84 \mathrm{~A}$ & $4.03 \mathrm{~A}$ & $19.6 \mathrm{D}$ \\
\hline 100 & & $0.76 \mathrm{~B}$ & $3.73 \mathrm{~B}$ & $118.7 \mathrm{C}$ \\
\hline 200 & & $0.61 \mathrm{C}$ & $3.32 \mathrm{C}$ & $184.4 \mathrm{~B}$ \\
\hline 300 & & $0.54 \mathrm{D}$ & $3.01 \mathrm{D}$ & $250.6 \mathrm{~A}$ \\
\hline \multicolumn{5}{|c|}{2007} \\
\hline 0 & & $0.92 \mathrm{~A}$ & 4.21 & $22.1 \mathrm{D}$ \\
\hline 100 & & $0.85 \quad \mathrm{~A}$ & 3.85 & $108.9 \mathrm{C}$ \\
\hline 200 & & $0.74 \quad \mathrm{~B}$ & 3.13 & $214.8 \quad \mathrm{~B}$ \\
\hline 300 & & $0.62 \mathrm{C}$ & 2.91 & $285.4 \mathrm{~A}$ \\
\hline
\end{tabular}

\section{Lead contents}

The results of this study showed that the concentration of $\mathrm{Pb}$ increased signifcantly to different extents in both tops and roots (Tables 6 and7). When soil $\mathrm{Pb}$ concentration reached $300 \mathrm{ppm}$, the lead contents in roots and leaves were as high as 497.2and $250.6, \mu \mathrm{g} / \mathrm{g}$; and 468.6 and $285.4 \mu \mathrm{g} / \mathrm{g}$, in the first and second seasons respectively. Thus the supply of $\mathrm{Pb}$ stimulated the accumulation of $\mathrm{Pb}$ not only in roots but also in tops. However, the accumulation of $\mathrm{Pb}$ was higher in roots than in tops at different $\mathrm{Pb}$ levels. This result agreed with that of Malkowski et al. (2002) who showed that the $\mathrm{Pb}$ concentration in the roots of corn seedlings increased with increasing $\mathrm{Pb}$ concentration. About $90 \%$ of $\mathrm{Pb}$ accumulated in a number of species of the Brassicase family and other plants were in the roots (Kumar et al., 1995). Roots can accumulate $\mathrm{Pb}$ up to 3-50 times more than leaves (Wozny et al., 1995). Lead translocation from roots to shoots takes place by loading in the xylem sap and translocating to the aboveground parts through the transpiration stream (Briat and Lebrun, 1999). $\mathrm{Pb}$ accumulation in the root 
takes place by binding with polysaccharides (Seregin and Ivanove, 1998), complexing with organic acids or binding to the cell walls in the roots and xylem vessels (Fathi, 1983) and thus might become immobile. The low allocation ratio of $\mathrm{Pb}$ between the roots and shoots may also be due to $\mathrm{Pb}$ movement in the root tissues which is usually prevented by the endodermis (Wierzbicka, 1987).

The relationship between applied $\mathrm{Pb}$ and changes in the $\mathrm{Pb}$ concentration of the leaves and roots was described mathematically (Figs1and2) by polynomial quadratic equations described in Snedecor and Cochran (1989)

$\mathrm{Y}_{\mathrm{i}}=\mathrm{B}_{\mathrm{o}}+\mathrm{B}_{1} \mathrm{X}_{\mathrm{i}}+\mathrm{B}_{2} \mathrm{X}_{\mathrm{i}}^{2}$

Where $\mathrm{Y}_{\mathrm{i}}$ is the predicted $\mathrm{Pb}$ content corresponding to lead applied rates $\mathrm{x}_{\mathrm{i}}$,

Table 7. Effect of $\mathrm{Pb}$ on elemental concentration of roots of radish plants during 2006 and 2007 seasons

\begin{tabular}{|c|c|c|c|}
\hline $\begin{array}{c}\text { Lead concentration } \\
\text { ppm }\end{array}$ & P\% & K\% & Pb ppm \\
\hline $\begin{array}{c}0 \\
100 \\
200 \\
300 \\
\end{array}$ & $\begin{array}{l}0.64 \mathrm{~A} \\
0.59 \mathrm{~A} \\
0.48 \mathrm{~B} \\
0.41 \mathrm{C}\end{array}$ & $\begin{array}{l}2.86 \mathrm{~A} \\
2.59 \mathrm{~B} \\
2.23 \mathrm{C} \\
1.91 \mathrm{D}\end{array}$ & $\begin{array}{c}24.1 \mathrm{D} \\
226.9 \mathrm{C} \\
318.77 \mathrm{~B} \\
497.2 \mathrm{~A}\end{array}$ \\
\hline $\begin{array}{c}0 \\
100 \\
200 \\
300\end{array}$ & $\begin{array}{l}0.76 \mathrm{~A} \\
0.76 \mathrm{~B} \\
0.673 \mathrm{C} \\
0.548 \mathrm{D}\end{array}$ & $\begin{array}{ll}2.93 & \mathrm{~A} \\
2.62 & \mathrm{AB} \\
2.32 & \mathrm{~B} \\
1.87 & \mathrm{C}\end{array}$ & $\begin{array}{ll}27.3 & \mathrm{D} \\
202.5 & \mathrm{C} \\
306.9 & \mathrm{~B} \\
468.6 & \mathrm{~A}\end{array}$ \\
\hline
\end{tabular}

Table 8. The polynomial quadratic equations expressing lead contents in roots and leaves of radish plants as affected by lead application in 2006 and 2007 seasons

\begin{tabular}{cc}
\hline \multicolumn{3}{c}{ Polynomial Quadratic Equations } \\
\hline \multicolumn{3}{c}{ Season 2006} \\
\hline Y roots $=-0.0006 \mathrm{x}^{2}+1.693 \mathrm{x}+33.985$ & $\mathrm{R}^{2}=0.9832$ \\
Y leaves $=-0.0001 \mathrm{x}^{2}+0.802 \mathrm{x}+21.445$ & $\mathrm{R}^{2}=0.9976$ \\
\hline \multicolumn{2}{c}{ Season 2007} \\
\hline Y roots $=-0.0003 \mathrm{x}^{2}+1.5296 \mathrm{x}+33.705$ & $\mathrm{R}^{2}=0.992$ \\
Y leaves $=-0.0004 \mathrm{x}^{2}+1.0173 \mathrm{x}+19.38$ & $\mathrm{R}^{2}=0.9963$ \\
\hline
\end{tabular}

Table 9. Experimental and predicted lead contents of roots and leaves of radish plants as affected by applied lead in 2006 and 2007 seasons

\begin{tabular}{|c|c|c|c|c|c|}
\hline \multicolumn{6}{|c|}{ Season 2006} \\
\hline \multicolumn{3}{|c|}{ Lead content (ug/g dry wt.) Roots } & \multicolumn{3}{|c|}{ Lead content (ug/g dry wt.) Leaves } \\
\hline Treatments & Exp & Pre & Treatments & Exp & Pre \\
\hline $\mathrm{Pb} 0$ & 24.1 & 34.0 & $\mathrm{~Pb} 0$ & 19.6 & 21.45 \\
\hline $\mathrm{Pb} 100$ & 226.9 & 197.33 & $\mathrm{~Pb} 100$ & 118.7 & 100.65 \\
\hline $\mathrm{Pb} 200$ & 318.7 & 348.67 & $\mathrm{~Pb} 200$ & 184.4 & 177.85 \\
\hline $\mathrm{Pb} 300$ & 497.2 & 488.01 & $\mathrm{~Pb} 300$ & 250.6 & 253.05 \\
\hline \multicolumn{3}{|c|}{$\mathrm{R}=0.9916$} & \multicolumn{3}{|c|}{$\mathrm{R}=0.9954$} \\
\hline \multicolumn{6}{|c|}{ Season 2007} \\
\hline \multicolumn{2}{|c|}{ Lead content (ug/g dry wt.) } & & \multicolumn{2}{|c|}{ Lead content (ug/g dry wt.) } & \\
\hline Treatments & $\operatorname{Exp}$ & Pre & Treatments & Exp & Pre \\
\hline $\mathrm{Pb0}$ & 27.3 & 33.71 & $\mathrm{~Pb} 0$ & 22.1 & 19.38 \\
\hline $\mathrm{Pb} 100$ & 202.5 & 183.67 & $\mathrm{~Pb} 100$ & 108.9 & 117.11 \\
\hline $\mathrm{Pb} 200$ & 306.9 & 327.63 & $\mathrm{~Pb} 200$ & 214.8 & 206.84 \\
\hline $\mathrm{Pb} 300$ & 468.6 & 465.59 & $\mathrm{~Pb} 300$ & 285.4 & 288.57 \\
\hline
\end{tabular}




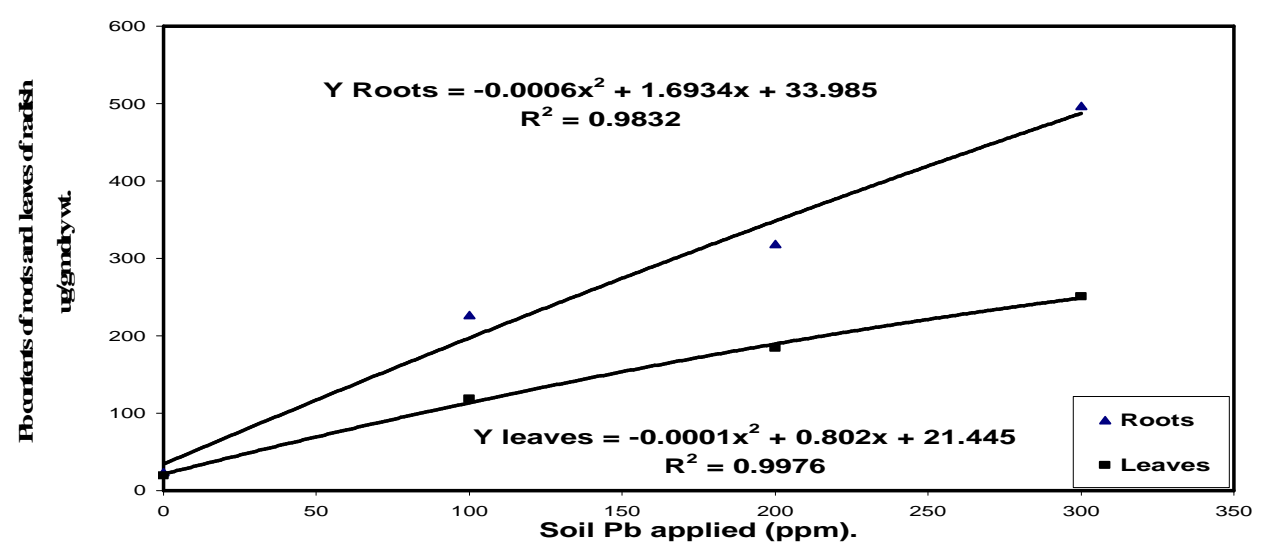

Fig. 1. The relationship betwen $\mathrm{Pb}$ applied and $\mathrm{Pb}$ contents of radish roots and leaves in 2006 season

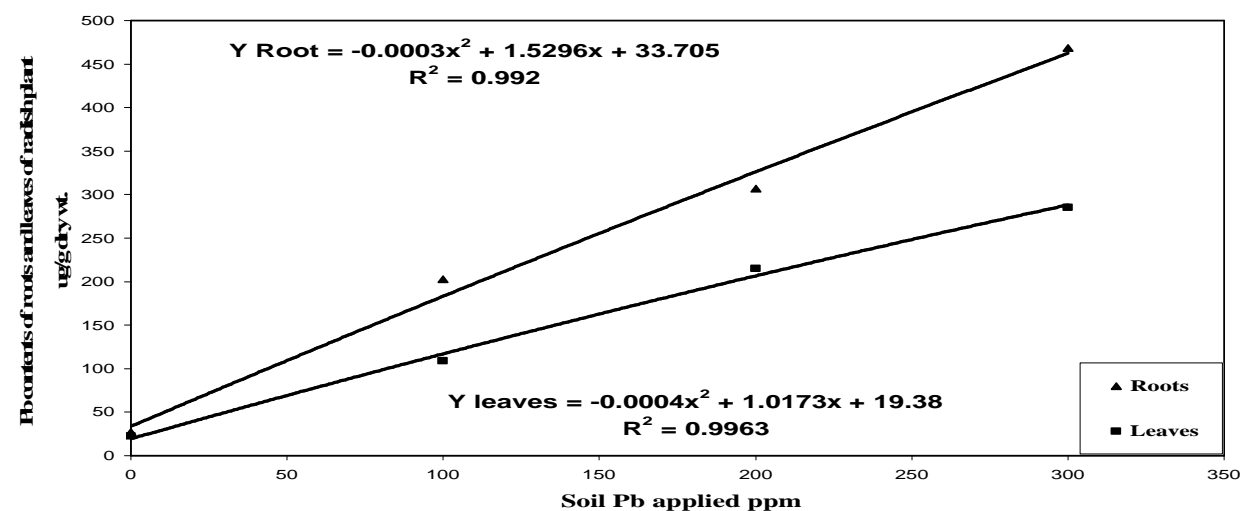

Fig. 2. The relationship betwen $\mathrm{Pb}$ applied and $\mathrm{Pb}$ contents of roots and leaves of radish plants in 2007 season

\section{REFERENCES}

Ahmed A. and H. Taijmir-Riahi (1993). Interaction of toxic metal ions $\mathrm{Cd}^{2+}, \mathrm{Hg}^{2+}$ and $\mathrm{Pb}$ with light-harvesting proteins of chloroplast thyolakoid membranes. J. Inorg. Biochem. 50: 235-243.

Al-Rawy .K.M. and A.M. Khalaf-allah. (1980). Design and analysis of Agricultural experiments.A Textbook. Elmousl Univ.press, Ninawa,Iraq. pp.487.

Begonia G.B., C.D. Davis, M.F. Begonia and C.N. Gary (1998). Growth responses of Indian mustard (Brassica Juncea L.) and its phytoextraction of lead from a contaminated soil . Bulletin of Environ . Contam. and Toxic. 61 (1): 38-43.

Briat J.F. and M. Lebrun, (1999). Plant responses to metal toxicity. Comptes Rendus Acad. Sci. Ser. III Sci., 322: 43-54.

Brown, J. and O. Lilliand (1946). Rapid determination of potassium and sodium in plant material and soil extracts of flame-photometry. Proc. Amer. Soc. Hort. Sci. 48: 341-346.

Burzynski M. (1987). The influence of lead and cadmium on the absorption and distribution of potassium, calcium, magnesium and iron in cucumber seedlings, Acta Physiol. Plantarum. 9: 229 -/238.
Champman D.H. and F.P. pratt. (1978). Methods of analysis for soil, plants and waters. Univ. of California Div., Agric., priced publication, 4034. pp.50 and 169.

Chattopadhyay S. B., P. K. Sahu, U. Thapa, and M. Niranjan Kuma. (2006). Effect of Microbial Amendments on Root and Seed Yield of Radish .Journal of Vegetable Science, Vol. 12(3) 89-103.

Cottenie A.; M. Verloo; G. Velgh and L. Kiekens and R. Camcrlynck. (1982). Chemical analysis of plant and soils. Lab. of Analytical and Agro. State Univ. Ghent Belgium.

Davies B.E. (1995): Lead in Heavy Metals in Soils, ed. B.J. Alloway, Blackie and Son Ltd., 206-223

Fathi, M. (1983). Binding of mercury, cadmium and lead in plant and animal tissues with respect to human nutrition. Anal. Chem., 316: 589-613.

Fayed A.M. (1997). Evolution of some cultivars and mutants of cow pea (Vigna unguiculata L. Walp) under Kafr EL Sheikh condition M.Sci. Thesis . Fac . Agric , Kafr ELSheikh, Tanta. University.

Fodor F., E. Sarvari, F. Lang, Z. Szigeti and E. Cseh. (1996). Effects of $\mathrm{Pb}$ and $\mathrm{Cd}$ on cucumber depending on the $\mathrm{Fe}-$ complex in the culture solution, J. Plant Physiol. 148: $434-439$. 
Hameed, N., Z.Siddiqui and S.Ahmed. (2001). Effects of copper and lead on germination, accumulation and phenolic contents of Spinancea oleracea and Lycopersicum esculentum. Pakistan journal of Biological sciences 4(7):809-811.

Haussling ,M., C.Jorns, G.Lehmbecker, C.Hecht-Buchholz and $\mathrm{H}$. Marschner. (1988). Ion and water uptake in relation to root development of Norway spruce (Picea abies L.),J.Plant Physiol. 133: 486-491.

Herrero E.M., A. Lopez-Gonzalvez, , M.A. Ruiz, , J.A. LucasGarcia, C. Barbas, (2003). Uptake and distribution of zinc, cadmium, lead and copper in Brassica napus var. oleifera and Helianthus annus grown in contaminated soils. - Inter. J. Phytoremed. 5: 153-167,

Iqbal, M.Z. and D.A. Siddiqui. (1992). Effects of lead toxicity on seed germionation and seedling growth of some tree species. Pakistan Journal of Scientific and Industrial Research, 35: 139-141.

Jackson M.L. (1967). Soil chemical analysis. Verlag. Prentia. Hall inc., Englewood. Cliffs, USA.

Jaja , E.T. and C.S. Odoemena. (2004). Effect of $\mathrm{Pb}, \mathrm{Cu}$ and Fe compounds on germination and early seedling growth of tomato varieties. J. Appl. Sci. Environ .8 (2): 51-53.

Kabata-Pendias, A. and Pendias, H. (1992). Trace elements in soils and plants: CRC.Press.Inc.Boca Raton,Florida. pp. $154-163$.

Khan D.H. and B. Frankland (1983). Effects of cadmium and lead on radish plants with particular reference to movement of metals through soil profile and plant. Plant Soil 7: 335-345, 1983.

Khan, S. and N.N. Khan. (1983). Influence of lead and cadmium on the growth and nutrient concentration of tomato and eggplant. Plant and Soil 74: 387-394.

Kumar P.B., V. Dushenkov, H. Motto and I. Raskin, (1995). phytoextraction: The use of plants to remove heavy metals from soils. Environ. Sci. Technol., 29: 1232-1238.

Liu D., W. Wang, F. Zhaoand, C. Lu. (1994). Effects of lead on growth ,cell division, and nucleolus of Allium cepa. Environ. Pollut. 86:1-4.

Malkowski E., A. Kita, W. Galas, W. Karcz and M. Kuperberg, (2002). Lead distribution in corn seedling (Zea mays L.) and its effect on growth and the concentrations of potassium and calcium. Plant and Soil., 37: 69-76

Mukherji S. and M. DasGupta. (1972). Characterization of copper toxicity in lettuce seedlings. Physoil. Pl., 27: 126129.

Nedelkoska T.V. and P.M. Doran (2000). Characteristics of heavy metal uptake by plants species with potential for phytoremediation and phytomining. Minerals Engineering 13: 549-561.

Obroucheva N. V., E .I. Bystrova, V. B. Ivanov, O.V. Antipova and I.V. Seregin. (1998). Root growth response to lead in young maize seedlings. Plant and soil 200: 5561.
Page A.L., R.H. Miller and D.R Keeneny . (1982). Methods of soil analysis. Part 2. chemical and microbiological properties. $2^{\text {nd }}$ edition. Agron. Madison, Wisconsin, USA.

Paivoke, A.E. (2002). Soil lead alters phytase activity and mineral nutrient balance of pisum sativum . J. Environ. Exp. Bot. 48: 61-73.

Redmann R.E. (1974). Osmotic and specific ions effects on the germination of alfalfa. Can. J. Bot., 52: 803-808.

Rooney C.P., R.G Mclaren, R.J. Cresswell. (1999). Distribution and phytoavailability of lead in a soil contaminated with lead shot. Water, Air and Soil Pollut. $116: 535-548$.

SAS. (1996). Software program. Cary, North Carolina State. Univ., Karl M Glsener. USA.

Seregin I.V. and V.B. Ivanove. (1998). The transport of cadmium and lead ions through root tissues. Russian J. Plant Physiol., 45: 780-785.

Snedecor G.W., W.G. Cochran (1989). Statistical Methods. Iowa State University Press, Ames, Iowa.

Stefanov K., K. Seizova, I. Popova, V. Petkov, G. Kimenov, S. Popov. (1995).Effect of lead ions on the phospholipid composition in leaves of Zea mays and Phaseolus vulgaris , J. Plant Physiol. 147:243-/246.

Talanova V.V, A.F. Titov, N.P. Boeva. (1999). The effect of cadmium and lead ions on growth and proline and abscisic acid contents in cucumber seedlings. - Russ. J. Plant Physiol. 46: 141-143.

Tomar, M., I. Kaur, , Neelu, A.K. Bhatnagar. (2000). Effect of enhanced $\mathrm{Pb}$ in soil on growth and development of Vigna radiate (Linn.) Wilczek. Indian J. Plant Physiol. 5, 13-18.

Van Assche F. and H. Clijsters (1990). Effects of metals on enzymes activityin plants, Plant Cell Environ. 13:195206.

Walker WM., J.E. Miller, J.J. Hassett. (1977). Effect of lead and cadmium upon the calcium, magnesium, potassium and phosphorus concentration in young corn plants. Soil Sci. 124:145-151.

Wasserman G.A., X. Liu, N.J. Lolacono and P. Factor-Litvak. (1997). Lead exposure and intelligence in 7-year-old children. Health Prospect. 105: 956-/962.

Wierzbicka M. (1987). Lead accumulation and its translocation barriers in roots of Allium cepa .Autoradiographic and ultrastructural studies. Plant Cell Environ. 10: 17-26.

Wierzbicka M. (1995). How lead loses its toxicity to plants. Acta Soc. Bot. Pol. 54: 81-91.

Wierzbicka M. and J. Obidzinska. (1998). The effect of lead on seed imbibition and germination in different plant species. Plant Sci. 137: 155-171.

Wozny A., J. Schneider and E.A. Gwozdz, (1995). The effects of lead and kinetin on greening barley leaves. Biol. Plant., 37: 541-552.

Xiong Z.T. (1998). Lead uptake and effects on seed germination and plant growth in a $\mathrm{Pb}$ hyperccumulator 
Brassica Pekinensis. Bull.Environ.Contam.Toxicol. 60 (2): 285-291.
Yang J.R., Z.P. Bao and S.Q. Zhang. (1993). The distribution and binding of $\mathrm{Cd}$ and $\mathrm{Pb}$ in plant cell, China Environ. Sci. 13: 263-268 


\section{دراسة تأثير تلوث الأراضي بالرصاص على الإنبات والنمو والخصول والتركيب الكيماوي للفجل}

حسن احمد الخطيب

النمو الخضرى ومحصول الجذور والاوراق مقارنة بالتربــة الغـير

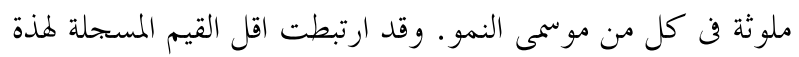

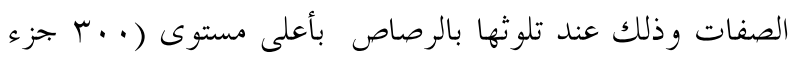

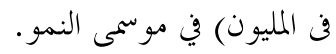
أمكن الحصول على علاقة كمية لدراسة تأثير العلاقـــة بــين

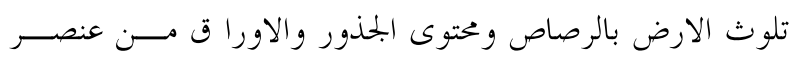

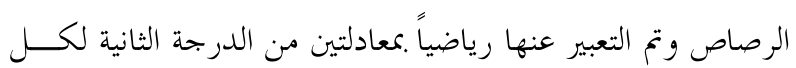
من الجذور والاوراق فن كل من موسمى النمو.

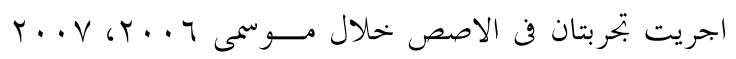

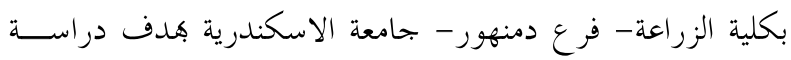

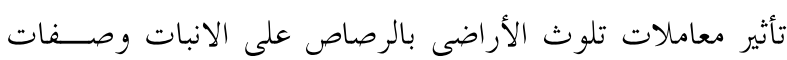

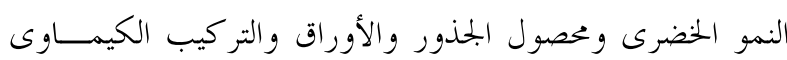

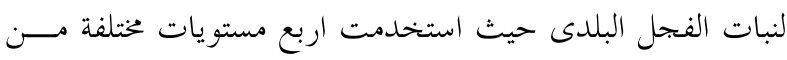

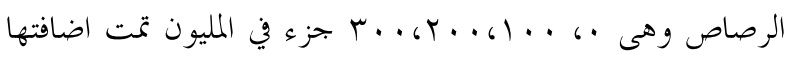

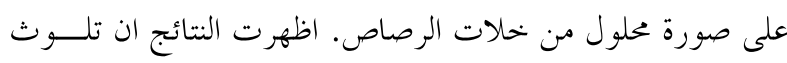

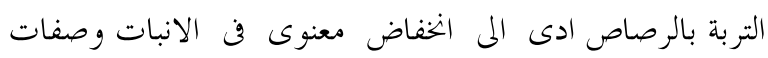

